\title{
Solid-State Mechanochemical Synthesis of Kaolinite-Urea Complexes for Application as Slow Release Fertilizer
}

\author{
Ehab M. AlShamaileh ${ }^{1}$, Aiman E. Al-Rawajfeh ${ }^{2 *}$, Mohammad R. Alrbaihat ${ }^{1}$ \\ 1 Department of Chemistry, The University of Jordan, Amman 11942, Jordan \\ 2 Department of Chemical Engineering, Tafila Technical University, Tafila 66110, Jordan \\ * Corresponding author's e-mail: aimanr@yahoo.com
}

\begin{abstract}
This study investigated a mechanochemical (MC) process for synthesizing a slow-release urea fertilizer by cogrinding the starting materials of $\left(\mathrm{NH}_{2}\right)_{2} \mathrm{CO}$ and amorphous kaolinite in a planetary ball mill. The tests with kaolinite contents ranging from 25 to 75 wt. \%, milling time ranging from 1 (h) to 3 (h) and mill rotational speeds from 200 to $700 \mathrm{rpm}$ were performed to evaluate the incorporation of $\left(\mathrm{NH}_{2}\right)_{2} \mathrm{CO}$ and release of nitrogen into the solution. The analyses conducted using XRD, TGA, FT-IR and KNDU (Kjeldahl Nitrogen Determination Unit) indicated that the $\mathrm{MC}$ process was successfully applied to incorporate $\left(\mathrm{NH}_{2}\right)_{2} \mathrm{CO}$ into the amorphous kaolinite structure. The release of nitrogen from the system (kaolinite- $\left(\mathrm{NH}_{2}\right)_{2} \mathrm{CO}$ ) when dispersed in water for $24 \mathrm{~h}$ reached up to $20 \%$ at $25 \%$ wt of kaolinite. Moreover, under the milling speed conditions for the system (kaolinite- $\left(\mathrm{NH}_{2}\right)_{2} \mathrm{CO}$ ), release of nitrogen reached between 25 and $40 \%$. These results indicated that the $\mathrm{MC}$ process can be developed to allow amorphous kaolinite to act as a carrier of nitrogen nutrients to be released slowly for use as fertilizer.
\end{abstract}

Keywords: mechanochemical; ball milling; slow-release; kaolinite; urea.

\section{INTRODUCTION}

Elemental nitrogen is considered to be one of the most important components in commercial fertilizers as well as a major nutrient source for food and biomass production in agriculture. However, considering the energy required for its synthesis, nitrogen fertilizers encounter high monetary costs. This is due to the fact that $50-70 \%$ of the nitrogen content in conventional fertilizers is lost to the soil through leaching and enhanced by the low nitrogen utilization efficiency (NUE) of plants (Kottegoda et al, 2013). The leaching of nitrogen can occur as water-soluble nitrates, emission as ammonia and nitrogen oxides, and soil microorganism-mediated incorporation into the soil organic material over time. The nitrate in agriculture soils moves into the reduced zone, where it is rapidly converted by the denitrifying bacteria to $\mathrm{N}_{2}$ and $\mathrm{N}_{2} \mathrm{O}$ gases which are unsuitable for, e.g. rice plants. Denitrification is generally reported as a major reason for the low efficiency of applied ammonium fertilizers (Kottegoda et al, 2013; Kottegoda et al, 2011).

The loss of nitrates upon using fertilizers by leaching is most noticeable in the soils with high percentage of sand. Recent studies suggest that $15-45 \%$ of the surface-applied ammonium- $\mathrm{N}$ fertilizers may be lost in the nitrification-denitrification processes. The low NUE is attributed mainly to ammonia volatilization, denitrification, leaching, and run off losses (Jones et al 2013).

Many attempts to increase the NUE value in conventional fertilizer formulations have been reported (Zhao et al., 2003; Wang et al., 2006; Li et al., 2007). Studies show that the control and slow released fertilizers (CRF/SRF) can improve the efficiency of using fertilizers effectively. Upon using lesser quantities, CRF and SRF can reduce the damage to the environment and ecology making them environmentally friendly fertilizers with minimal pollution. Therefore, CRF and SRF contribute efficiently to the loss of control of 
fertilizers (Zhao et al., 2003; Wang et al., 2006; Li et al., 2007).

There are hundreds of different clay minerals with different structures and many contain neutral or charged layers with various elemental composition. Some clay minerals possess very important properties such as those based on layered compounds (LeBaron et al., 1999). One of the most important properties of layered compound is the capacity to intercalate species (neutral atoms, ions or molecules) into the inter-layer spaces. The study of intercalation reactions in clay minerals is a very large research field (Gardolinski, 2000).

One of the famous applications of nanostructured materials such as clays to develop SRF have been studied in recent years. The layers of nanostructured clay minerals have large active surface areas which are exploited to provide enhanced surface interaction with the fertilizer elements. Mechanochemical activation of layered minerals, especially clay minerals, has been studied extensively in the past and the observed effects include: increase of defects in the materials, increases in the chemical reactivity and solubility of the minerals, reduction of thermal stability and mechanochemical intercalation (Zhang et al., 2012; Hrachova et al., 2007; Vizcayno et al., 2010; Sun, 2011; Mako et al., 2014; Borges et al., 2015).

kaolinite is a type of a clay mineral consisting mainly of hydrated aluminum silicate or kaolinite formed through hydrothermal alteration of feldspar and muscovite, usually containing quartz (Solihin et al., 2011). kaolinite is usually represented by the $\mathrm{Si}_{2} \mathrm{Al}_{2} \mathrm{O}_{5}(\mathrm{OH})_{4}$ formula and/ or other forms, including $\mathrm{Al}_{2} \mathrm{O}_{3} \cdot 2 \mathrm{SiO}_{2} \cdot 2 \mathrm{H}_{2} \mathrm{O}$, $\mathrm{Al}_{2} \mathrm{O}_{7} \mathrm{Si}_{2} \cdot 2 \mathrm{H}_{2} \mathrm{O}$, which builds up by a sheet structure composed of $\mathrm{SiO}_{4}$ tetrahedral sheets, and $\mathrm{Al}(\mathrm{O}, \mathrm{OH})_{6}$ octahedral sheets $\left(\left[\mathrm{Si}_{2} \mathrm{O}_{5}\right]^{2-}\right.$ sheet and $\left[\mathrm{Al}_{2}(\mathrm{OH})_{4}\right]^{2+}$ sheet) with pseudo-hexagonal symmetry that are created from planes, which are occupied as follows:

$$
\mathrm{O}_{6}-\mathrm{Si}_{4}-\mathrm{O}_{4}-(\mathrm{OH})_{2}-\mathrm{Al}_{4}-(\mathrm{OH})_{6} \text {. }
$$

Kaolinite is an important industrial mineral, which is used in many applications, including paper filling and coating, refractory, ceramic, food additives and was used as the reservoir and cache of nutrient elements (Solihin et al., 2011).

Urea is a fertilizer material which can be used for direct application to crops or in the preparation of blended fertilizers (Roshanravan et al., 2014). Man et al. (2004) intercalated urea into the montmorillonite layers to prepare a controlled-release urea-based fertilizer. According to the documented result, about $80 \%$ of the intercalated urea was decomposed in water within 30 days (Man et al., 2004). Additionally, UrenaAmate et al. (2011) investigated a formulation of nitrate modified hydrotalcite-like layered double hydroxide (LDH) and hydroxypropyl methylcellulose (HPMC) as a nitrogen based controlled release fertilizer. The system with the highest LDH/ HPMC ratio produced the slowest release ratio (around 87\%) after 180 hours in the simulated soil solution (Man et al., 2004). The intercalation of kaolinite by urea has been studied in numerous works (Valaskova et al., 2007; Rutkai et al., 2009). However, previous studies have focused only on the intercalation of urea as the guest molecule between the clay nano-layers rather than on the nitrogen release behavior, which is the main focus of this section.

In the current study, we aimed at producing potential slow-release fertilizers with nitrogen, phosphorus and urea $\left(\left(\mathrm{NH}_{2}\right)_{2} \mathrm{CO}\right)$. A milling operation was performed for the kaolinite - Urea system to completely reduce the kaolinite structure to amorphous phase. A mechanochemical reaction was used to obtain the necessary chemical bonding between $\mathrm{NH}_{2}-\mathrm{Al}-\mathrm{Si}-\mathrm{P}-\mathrm{O}$ as amorphous phase. The new product was targeted to give a water-insoluble property so the release of nitrogen from urea nutrients into the soil can be controlled and offered as SRF or CRF fertilizer. Different milling conditions and kaolinite addition ratios were investigated to obtain the optimum milled products with desired properties.

\section{METHODOLOGY}

\section{Materials and mechanochemical process}

The mechanochemical reactions between high-purity kaolinite from Wadi Araba-Jordan, $\left(\mathrm{Al}_{2} \mathrm{Si}_{2} \mathrm{O}_{5}(\mathrm{OH})_{4}\right)$ (Bayook et al., 1992; Barjous et al., 1997) and urea $\left(\mathrm{CON}_{2} \mathrm{H}_{4}\right)$ as commercial fertilizer were investiated. A $6.0 \mathrm{~g}$ sample mixture of starting materials with varying weight ratios (see Table 1) and ball/sample weight ratio of about 10 was milled for $120 \mathrm{~min}$ at fixed milling in a planetary ball mill (Pulverisette-7, Fritsch, Germany), which had two mill pots $\left(45 \mathrm{~cm}^{3}\right.$ inner volume each) made of zirconium with 6 Zirconia-balls of $15 \mathrm{~mm}$ diameter. In order to avoid excessive heat 
during milling at all experiments, the operation was conducted by alternating $10 \mathrm{~min}$ of milling with $5 \mathrm{~min}$ of rest.

Three series of experiments were performed to observe the effect of different mole ratios of kaolinite: urea, milling speed and duration on the nutrient released of samples. Table 1 shows three different chemical compositions (mole ratios) that were investigated.

The milling speed used in this experiment ranged between 200 and $700 \mathrm{rpm}$ at 3:1 mole ratio of kaolinite: Urea and milling time was fixed at $120 \mathrm{~min}$. The milling time for the complex was ranged between 60 and $180 \mathrm{~min}$ when (3-kaolinite:1-urea) mole ratio $600 \mathrm{rpm}$ milling speed were used.

\section{Characterization}

Before and after milling, the samples were examined with X-ray diffraction (XRD, Rigaku, Japan), using $\mathrm{Cu} \mathrm{K}-\alpha$ radiation within a recorded range of $2 \theta$ from $5^{\circ}$ to $90^{\circ}$. A Fourier transformation infrared spectrometer (FTIR, NEXUS, EPS-870) was used to analyze the prepared samples using an advanced sensor (not $\mathrm{KBr}$ method) scanned from 4000 to $400 \mathrm{~cm}^{-1}$ with a resolution of $2 \mathrm{~cm}^{-1}$. A thermal gravimetric/differential thermal analysis (using STA-409 PC, NETZSCH) was carried out in an $\mathrm{N}_{2}$ atmosphere at a heating rate of $10^{\circ} \mathrm{C} / \mathrm{min}$ from room temperature to $1000^{\circ} \mathrm{C}$.

Leaching experiments on the ground samples in distilled water were carried out in a $100-\mathrm{mL}$ glass beaker with the parameters at room temperature: $1 \mathrm{~g}$ of ground sample; $20 \mathrm{~mL}$ of distilled water and leaching times was $24 \mathrm{~h}, 168 \mathrm{~h}$ and $336 \mathrm{~h}$ for urea. After leaching, the solid-liquid separation was performed by vacuum filtration with a filter paper of $0.45 \mu \mathrm{m}$ pore size. The quantity of nutrient released in the filtrate was measured using Kjeldahl Nitrogen Determination to determine the total nitrogen released from urea.

\section{RESULTS AND DISCUSSION}

It was possible to study the influence of speed and time of milling in the high-energy ball-mill. For this reason, a series of experiments were performed, which involved the milling of kaolinite and urea to establish processing conditions that maximize the slow-release behavior of nutrient.
The XRD patterns of kaolinite- $\left(\mathrm{NH}_{2}\right)_{2} \mathrm{CO}$ (3:1 weight ratio) sample mixture milled for $120 \mathrm{~min}$ at $600 \mathrm{rpm}$ mill speed (Fig. 1) indicated that the starting materials were completely reduced to amorphous state. Characteristic peaks of urea shifted in products, indicating that higher mill speeds and sufficient amount of the kaolinite content were required to reduce the starting materials to amorphous state and allow incorporation of $\left(\mathrm{NH}_{2}\right)_{2} \mathrm{CO}$ into the kaolinite structure.

\section{Effect of starting materials mass percentage for mechanochemical synthesis of kaolinite- urea system}

The FT-IR spectra presented in Figure 2 showed that at different mass ratio of kaolinite to $\left.\left(\mathrm{NH}_{2}\right)_{2} \mathrm{CO}\right)$, characteristic spectrums corresponding to $\left.\left(\mathrm{NH}_{2}\right)_{2} \mathrm{CO}\right)$ had disappeared in the milled products like as kaolinite peaks ranged from $3620-3686 \mathrm{~cm}^{-1}$ that exist in Fig. 2a, which could suggest that $\left.\left(\mathrm{NH}_{2}\right)_{2} \mathrm{CO}\right)$ has been incorporated into amorphous structure of kaolinite.

The samples $(25 \%$ kaolinite, $50 \%$ kaolinite and $75 \%$ kaolinite) showed that the mechanochemical amorphization was related to the dehydroxylation of the kaolinite, as the typical bands of the inner surface hydroxyls $\left(3700-3622 \mathrm{~cm}^{-1}\right)$ and internal octahedral layer hydroxyls $\left(3620 \mathrm{~cm}^{-1}\right)$ had disappeared. According to the generally accepted concept of mechanochemical-dehydroxylation, these hydroxyl groups form coordinated water molecules by proton transfer. Clear band on $\left.\left(\mathrm{NH}_{2}\right)_{2} \mathrm{CO}\right)$ spectrum at $\left(1146 \mathrm{~cm}^{-1}\right)$ had been up field shifted in 25\% kaolinite and 50\% kaolinite samples and to be disappeared in ( $75 \%$ kaolinite) sample which indicated to completely intercalation of $\left.\left(\mathrm{NH}_{2}\right)_{2} \mathrm{CO}\right)$ in kaolinite, Furthermore, in the region around $1000 \mathrm{~cm}^{-1}$, distinct broad bands were observed for all samples, due to the overlap of the vibrations of the Al-OH, Si-O and P-O groups (Fukamachi et al., 2007).

The mass loss characteristics behavior of the kaolinite mixtures $\left.-\left(\mathrm{NH}_{2}\right)_{2} \mathrm{CO}\right)$ (different weight percentages) milled for $120 \mathrm{~min}$ at fixed mill speeds $(600 \mathrm{rpm})$ is shown in Figure 3. One mass loss peak down at $180^{\circ} \mathrm{C}$ seen clearly only for

Table 1. Chemical composition of starting mixture investigated

\begin{tabular}{|l|c|c|c|}
\hline \multicolumn{4}{|c|}{ Mole ratio } \\
\hline Kaolinite : Urea & $(1: 3)$ & $(1: 1)$ & $(3: 1)$ \\
\hline
\end{tabular}




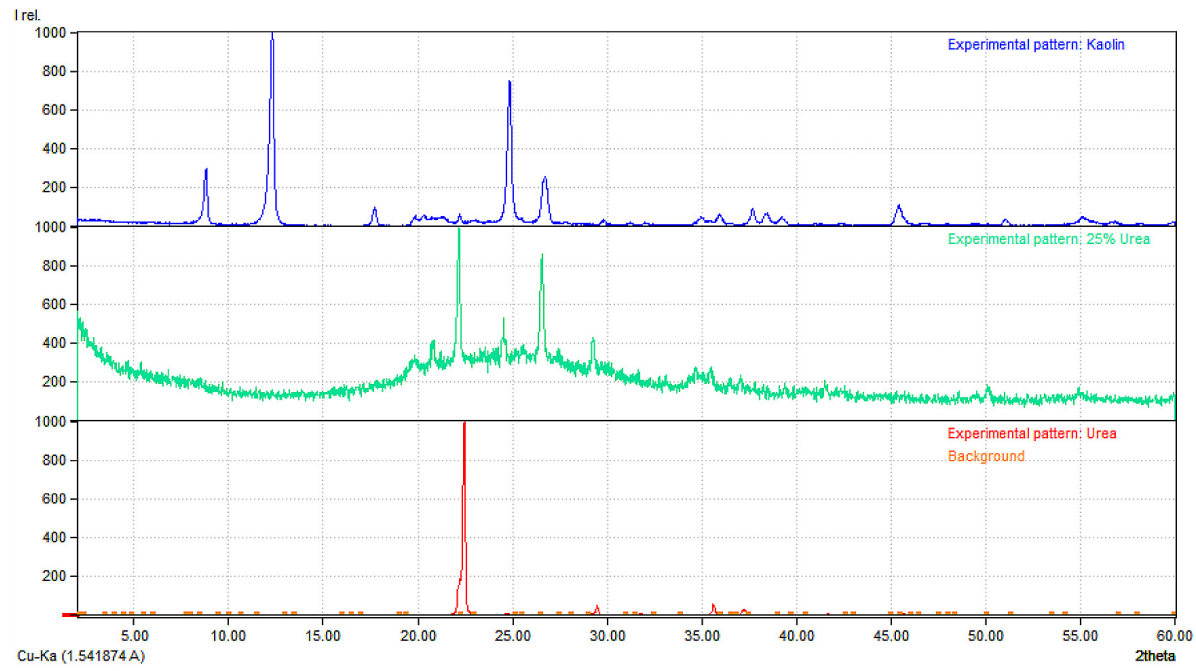

Fig. 1. XRD patterns of kaolinite- $\left(\mathrm{NH}_{2}\right)_{2} \mathrm{CO}(3: 1 \mathrm{wt}$ ratio) sample mixtures milled for $120 \mathrm{~min}$ at $600 \mathrm{rpm}$

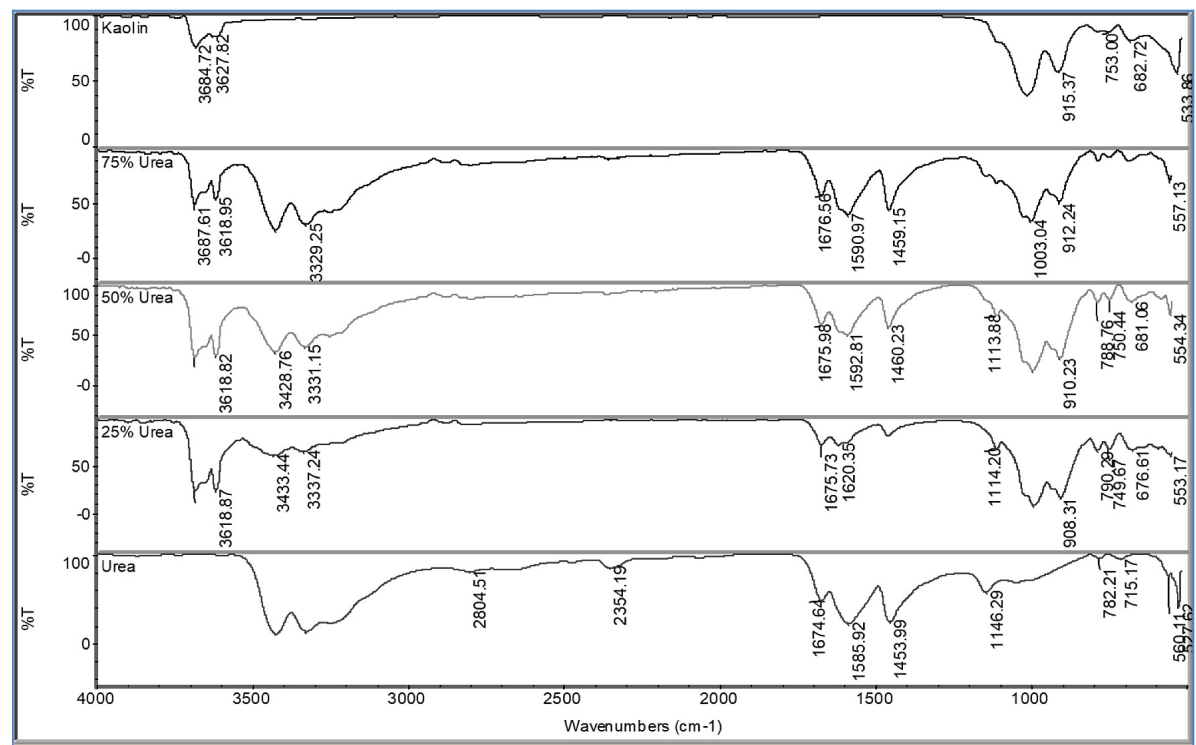

Fig. 2. FTIR spectra of samples (kaolinite-( $\left.\mathrm{NH}_{2}\right)_{2} \mathrm{CO}$ ) (a) without milling for different mole ratios, and (b) milled at speed $600 \mathrm{rpm}$ for different mole ratios

sample mixture (25\% kaolinite: $\left.75 \%\left(\mathrm{NH}_{2}\right)_{2} \mathrm{CO}\right)$ ) with complete incorporation of $\left.\left(\mathrm{NH}_{2}\right)_{2} \mathrm{CO}\right)$ into the amorphous structure of the kaolinite system. On the other hand, two mass loss had appeared when the (50\%:50\%) and (75\% kaolinite: $25 \%$ $\left.\left(\mathrm{NH}_{2}\right)_{2} \mathrm{CO}\right)$ ) mole ratios were used. Its appearance during the thermal decomposition indicates the mechanochemical reaction did not finish and there was some urea that did not intercalate with kaolinite; it also illustrates that the milling process at high mass ratio for kaolinite: $\left.\left(\mathrm{NH}_{2}\right)_{2} \mathrm{CO}\right)$ can promote the synthesis of a N-Si-P-O system.

The nutrient release behavior when dispersed in water for the sample mixtures milled with varying content of kaolinite is shown in Figure 4. At 25 wt. \% kaolinite addition, the release of nutrients dispersed in water reached over $81 \%$ and closer to $100 \%$ but decreased to between 30 and $50 \%$ for the kaolinite content at $50 \mathrm{wt}$. \% and was further reduced to below $22 \%$ for sample mixture with kaolinite content at 75 wt. \%. The decrease of nutrients release into solution indicated that $\left(\mathrm{NH}_{2}\right)_{2} \mathrm{CO}$ on impact of milling was incorporated into $\mathrm{Al}-\mathrm{Si}-\mathrm{O}$ network.

\section{Effect of milling speed on mechanochemical synthesis of kaolinite - $\left(\mathrm{NH}_{2}\right)_{2} \mathrm{CO}$ system as SRF}

The effect of mill rotational speed on amorphization of the kaolinite- $\left(\mathrm{NH}_{2}\right)_{2} \mathrm{CO}(3: 1 \mathrm{wt}$ ratio) sample mixture is shown in Figure 5. The milling time for all experimental runs was fixed 


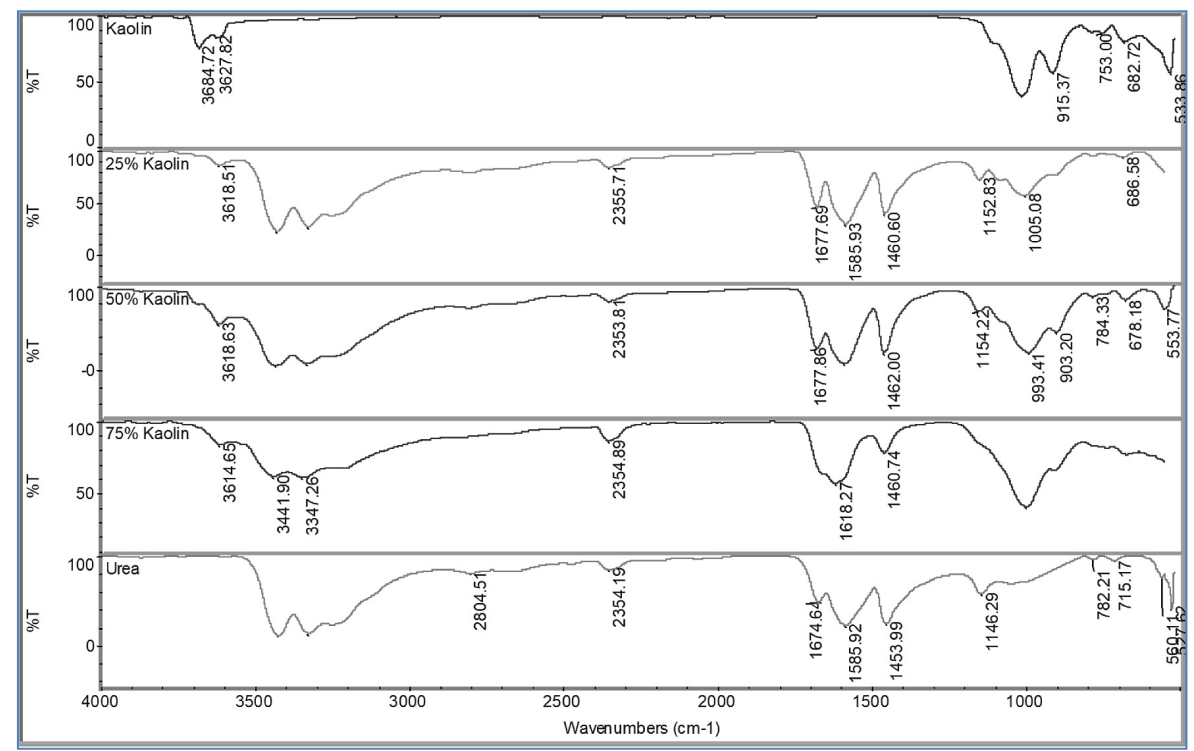

Fig. 3. TGA patterns of (kaolinite - $\left(\mathrm{NH}_{2}\right)_{2} \mathrm{CO}$ ) (different weight ratio) sample mixture milled for $120 \mathrm{~min}$ at fixed mill rotational speeds $(600 \mathrm{rpm})$

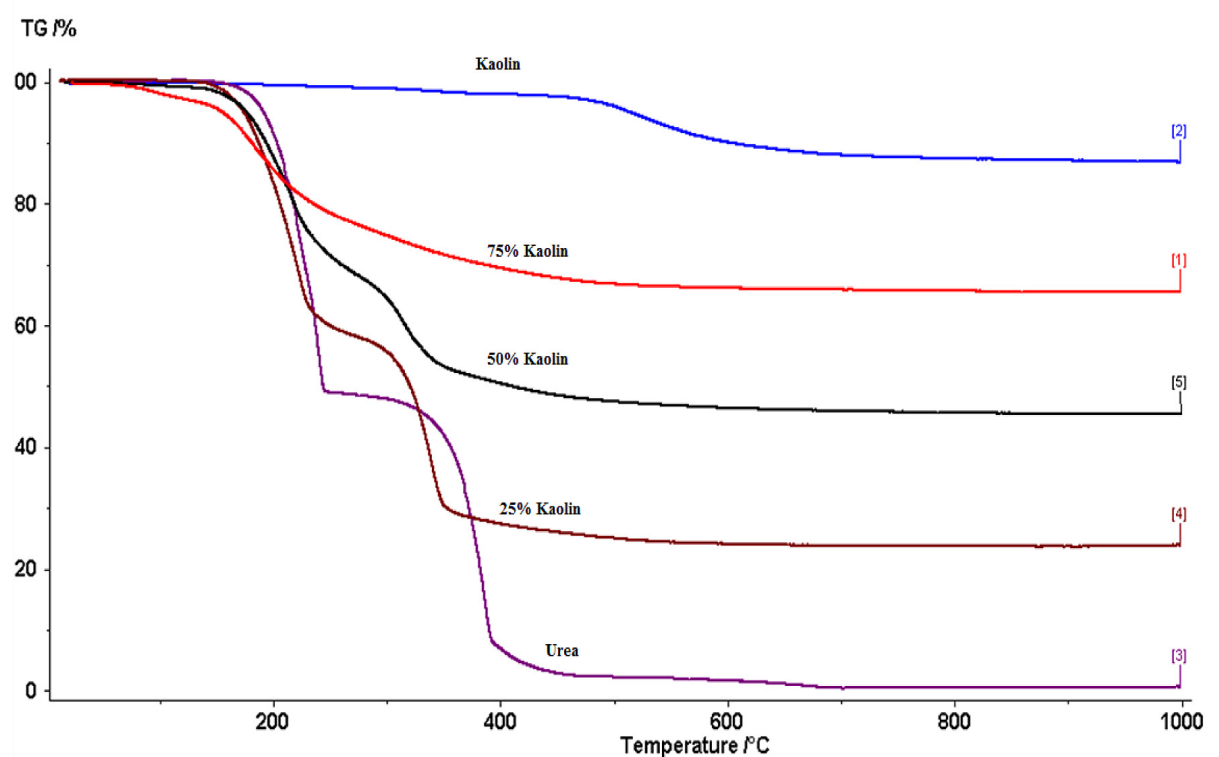

Fig. 4. Nutrients release profile of kaolinite- $\left(\mathrm{NH}_{2}\right)_{2} \mathrm{CO}$ sample system with varying amounts of kaolinite (wt \%) milled for $120 \mathrm{~min}$ at $600 \mathrm{rpm}$

at $120 \mathrm{~min}$ and the mill rotational speeds ranged between 200 and $700 \mathrm{rpm}$. The FT-IR spectra showed that at lower mill rotational speeds, ranging from 200 to $400 \mathrm{rpm}$, the characteristic spectrums corresponding to $\left(\mathrm{NH}_{2}\right)_{2} \mathrm{CO}$ remained in the milled products like as kaolinite peaks ranged from $3620-3686 \mathrm{~cm}^{-1}$. However, disappearance of previous peaks at mill speeds above $400 \mathrm{rpm}$ indicated that the starting samples were reduced to amorphous state, which could suggest that $\left(\mathrm{NH}_{2}\right)_{2} \mathrm{CO}$ had been incorporated into amorphous structure of Kaolinite.
Moreover, the N-H broad bands located between $3470-3200 \mathrm{~cm}^{-1}$ were gradualy decreased, after the gradual increase of samples milling, which illustrated the formation new product, i.e. a kaolinite-( $\left(\mathrm{NH}_{2}\right)_{2} \mathrm{CO}$ system when high milling speed used.

Additionally, the thermal gravimetric analysis presented in Figure 6 proved that the measured mass loss of $11.5 \%$, due to the thermal dehydroxylation of the Kaolinite, is in good agreement with the expected value of $13.96 \%$, thus proving the good purity of the starting Kaolinite [14]. 


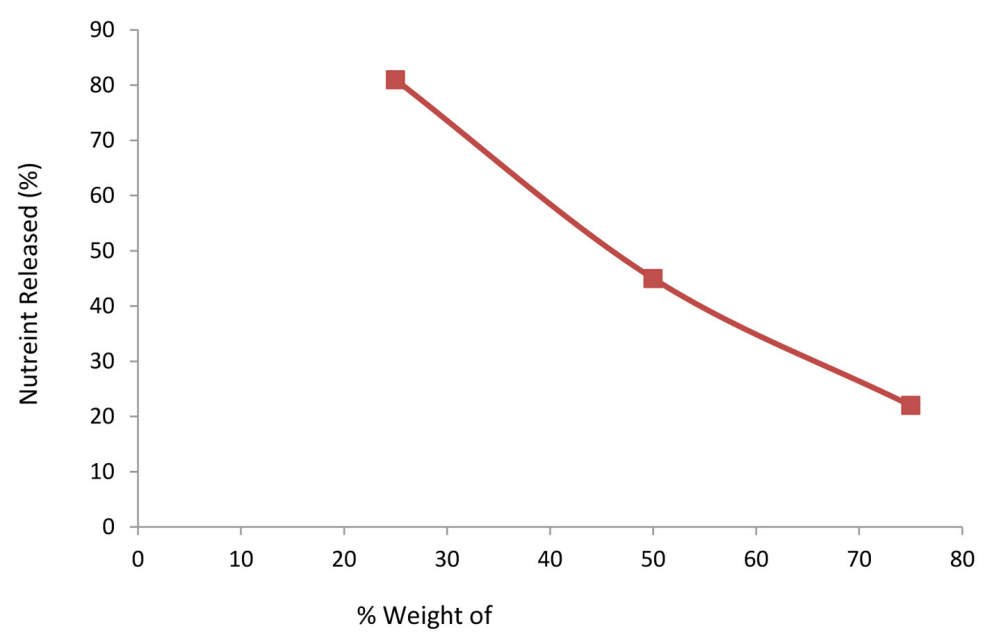

Fig. 5. FTIR spectra of samples (kaolinite- $\left(\mathrm{NH}_{2}\right)_{2} \mathrm{CO},(3: 1)$ mole ratios milled at different rotating speed for 2 (h)

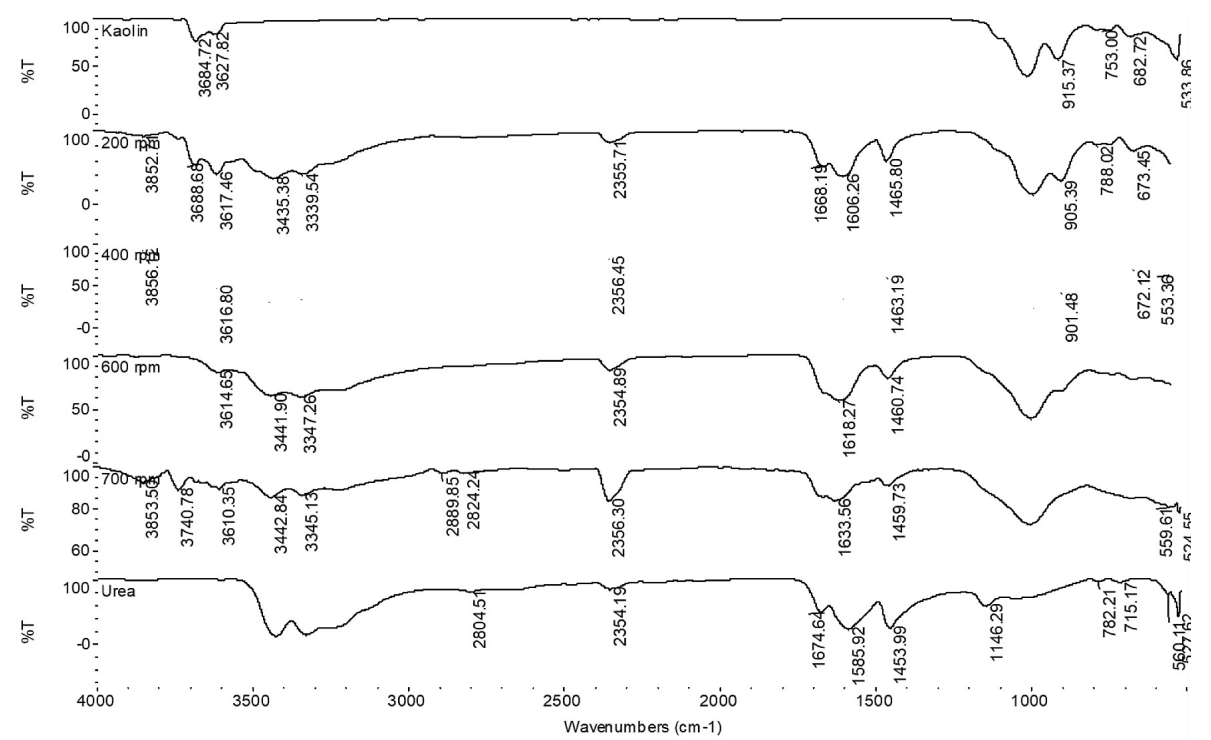

Fig. 6. TGA patterns of kaolinite-( $\left(\mathrm{NH}_{2}\right)_{2} \mathrm{CO}(75 \%: 25 \%$ weight ratio) sample mixture milled for 2 (h) at different mill rotational speeds

Basically, the urea molecules decompose in two steps, with endothermic peaks at $225^{\circ} \mathrm{C}, 300^{\circ} \mathrm{C}$ and $425^{\circ} \mathrm{C}$ for (kaolinite-urea) milled at $200 \mathrm{rpm}$. However, decomposing into one step for sample milled at $700 \mathrm{rpm}$ at $150^{\circ} \mathrm{C}$ (Fig. 6), which illustrates that the intercalation reaction is facilitated at high milling speed. The mass-loss characteristics of the starting materials were not observed in the (kaolinite-urea) samples milled at over $400 \mathrm{rpm}$, which attests to their destruction during grinding; the observed behavior was in agreement with other instrumental techniques, which showed the formation of amorphous phases derived from the mixture of the reagents.

The nutrients release behavior of kaolinite$\left(\mathrm{NH}_{2}\right)_{2} \mathrm{CO}(3: 1 \mathrm{wt}$ ratio) samples as a function of mill rotational speeds when dispersed in water for $24 \mathrm{~h}$ is shown in Figure 7. For the samples milled at $200 \mathrm{rpm}$, urea was close to complete dissolution into water. This result corresponds well with FT-IR data (Fig. 5), where the easily soluble $\left(\mathrm{NH}_{2}\right)_{2} \mathrm{CO}$ patterns continued to remain in the milled products and this indicated that the nutrients have not yet been incorporated into the kaolinite structure. For the sample mixtures milled at $400 \mathrm{rpm}$ and above, where complete amorphization was observed, the subsequent release of nutrients decreased and reached an average of around $20-30 \%$ in $24 \mathrm{~h}$. This result showed that higher mill rotational speeds were required to reduce the starting materials to amorphous phase and allow incorporation of the nutrients into the kaolinite structure. 


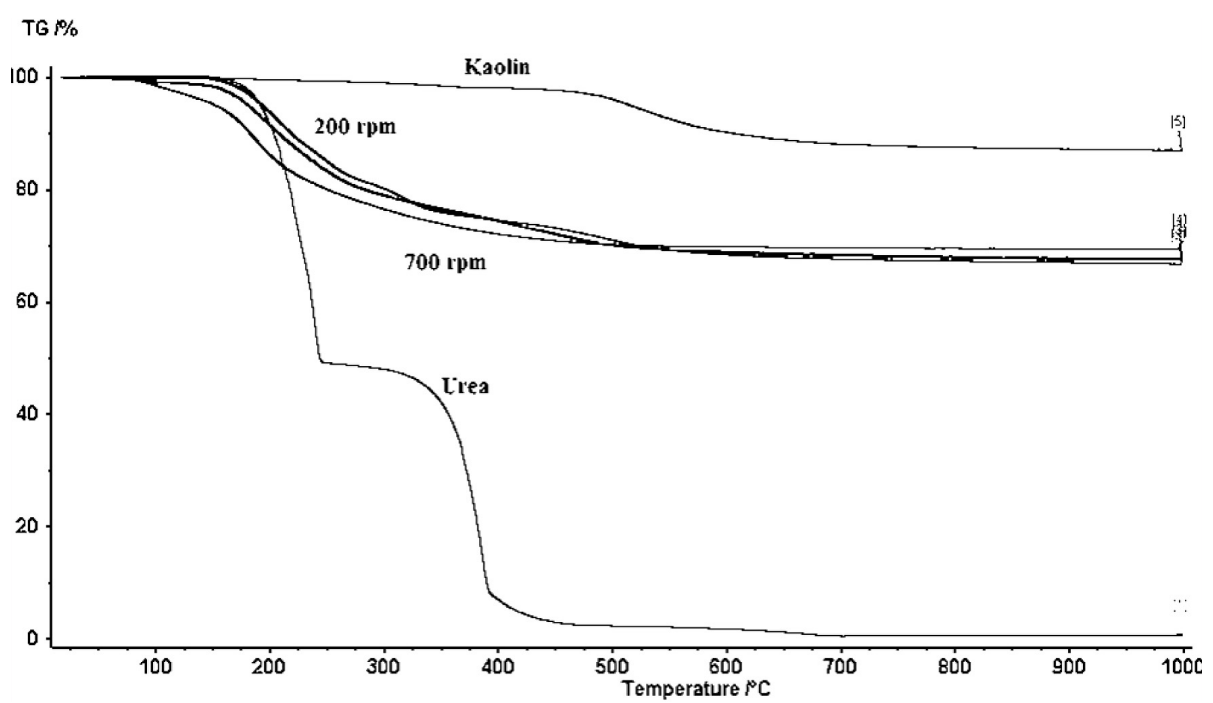

Fig. 7. Nutrients release profile of kaolinite- $\left(\mathrm{NH}_{2}\right)_{2} \mathrm{CO}(3: 1 \mathrm{wt}$ ratio) sample mixtures milled for $120 \mathrm{~min}$ at different mill speeds and dispersed in water for $24 \mathrm{~h}$

\section{Effect of milling time on mechanochemical synthesis of (kaolinite- $\left.\left(\mathrm{NH}_{2}\right)_{2} \mathrm{CO}\right)$ as SRF}

The FTIR spectra of (kaolinite: $\left(\mathrm{NH}_{2}\right)_{2} \mathrm{CO}$ ) samples have a ratio $3: 1$ that milled at $\mathrm{t}$ $600 \mathrm{rpm}$ for several different durations are depicted in Figure 8. It can be seen that when the time of rotational milling increased, the bond vibration intensity decreased until disappearance, like in the peak of around $915 \mathrm{~cm}^{-1}$ in kaolinite and broad peak of N-H bonds in urea at $3200-3400 \mathrm{~cm}^{-1}$. Additionally, the peaks with high absorption intensity, at $\left(3620-3690 \mathrm{~cm}^{-1}\right)$, could not be observed on the different milled samples, indicating that the intercalation take place. When the duration reached $120 \mathrm{~min}$ and then $180 \mathrm{~min}$, the intensity of the peaks decreased. However, disappearance of peaks at milling time above than
120 min indicated that the starting samples were reduced to amorphous state, which could suggest that $\left(\mathrm{NH}_{2}\right)_{2} \mathrm{CO}$ has been incorporated into amorphous structure of kaolinite.

The mass-loss characteristics of the starting materials were not observed in the milled samples of urea Figure 9, which attests to their destruction during grinding; the observed behavior agreed with other instrumental techniques, which showed the formation of amorphous phases derived from the mixture of the reagents.

The release profile of $\left(\mathrm{NH}_{2}\right)_{2} \mathrm{CO}$ nutrients for the kaolinite- $\left(\mathrm{NH}_{2}\right)_{2} \mathrm{CO}$ (3:1 wt ratio) sample mixtures milled at different mill time and dispersed in water for $24 \mathrm{~h}$ is shown in Figure 10. For the sample mixtures prepared at 180 min,the release of urea reached over $20-30 \%$ indicating that higher mill duration is required to effect

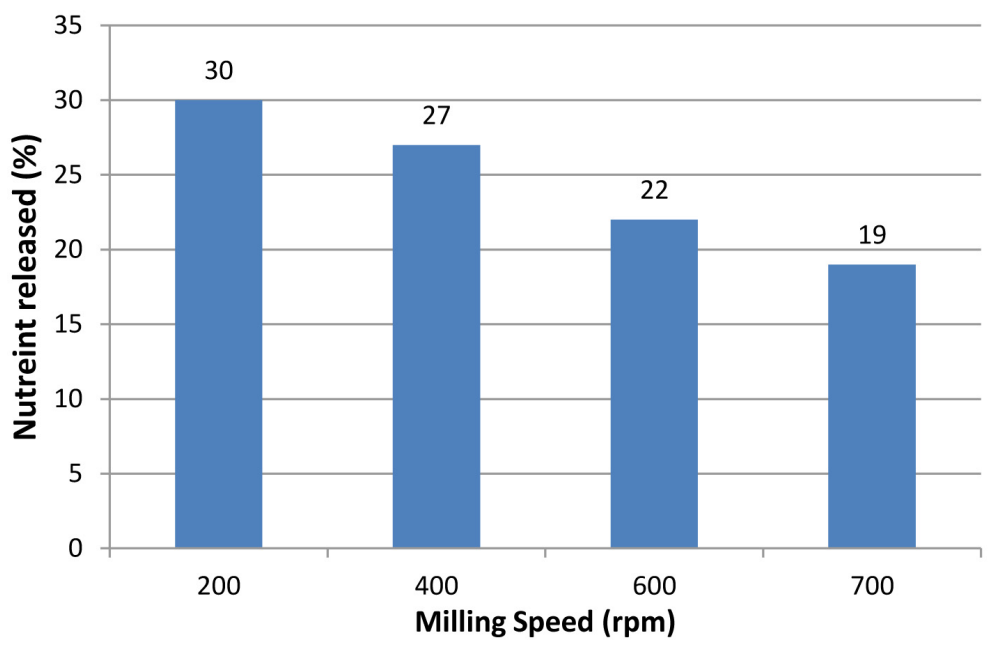

Fig. 8. FTIR spectra of samples (kaolinite-( $\left.\mathrm{NH}_{2}\right)_{2} \mathrm{CO},(3: 1)$ mole ratios. milled at speed $600 \mathrm{rpm}$ for different duration 


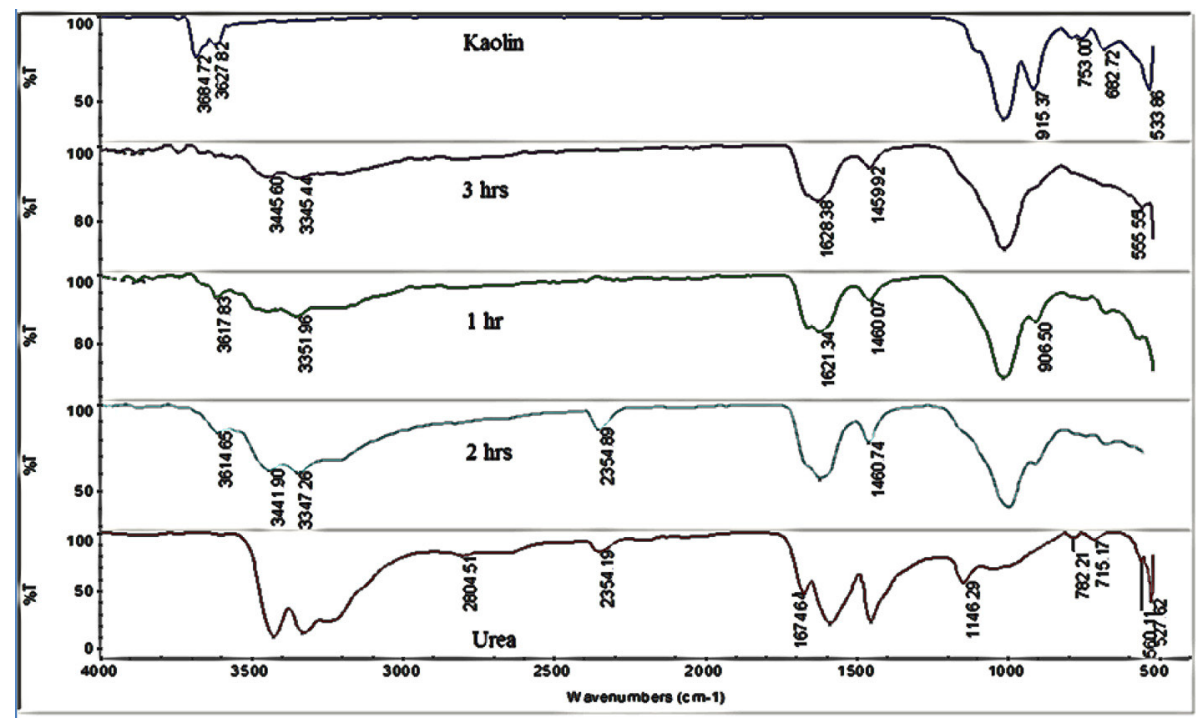

Fig. 9. TGA patterns of Kaolinite-( $\left(\mathrm{NH}_{2}\right)_{2} \mathrm{CO}(3: 1 \mathrm{wt}$ ratio) sample mixture milled at speed $600 \mathrm{rpm}$ for different milling time

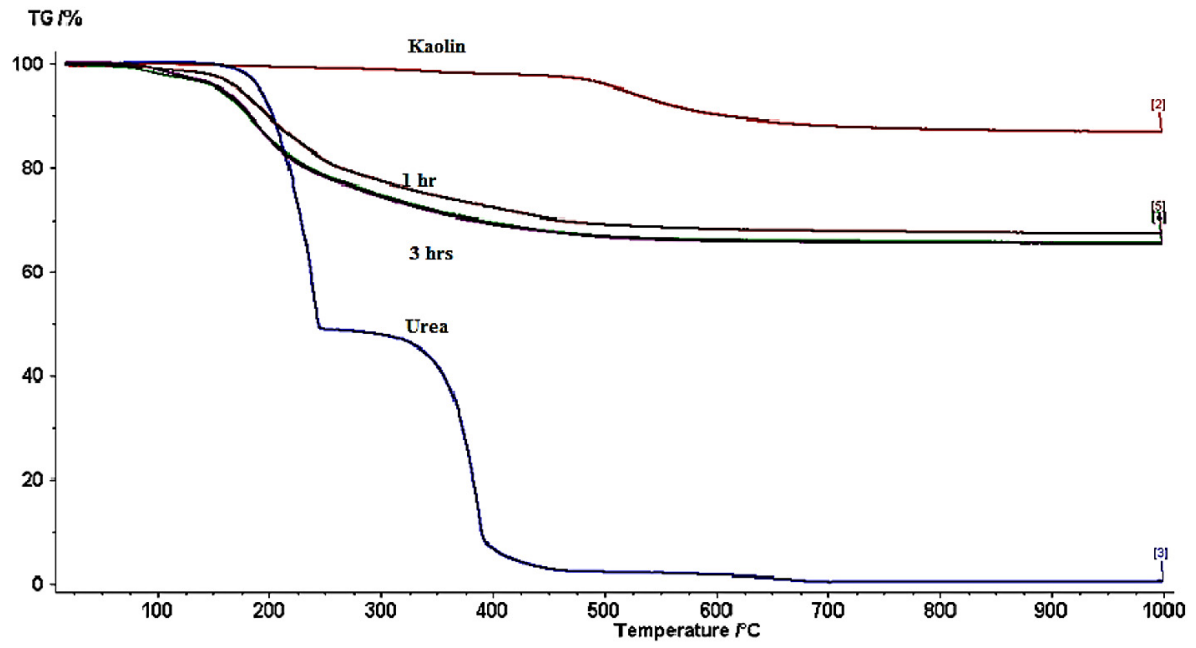

Fig. 10. Nutrients release profile of kaolinite-( $\left.\mathrm{NH}_{2}\right)_{2} \mathrm{CO}(3: 1 \mathrm{wt}$ ratio $)$ sample mixtures milled at $600 \mathrm{rpm}$ for different milling time and dispersed in water for $24 \mathrm{~h}$

complete amorphization of starting materials to allow incorporation of $\left(\mathrm{NH}_{2}\right)_{2} \mathrm{CO}$ into the amorphous kaolinite structure. When the milling time was decreased from 180 to $120 \mathrm{rpm}$, the release of $\left(\mathrm{NH}_{2}\right)_{2} \mathrm{CO}$ nutrients into solution significantly increased, reaching around $30-40 \%$ at $600 \mathrm{rpm}$ and remained around $45 \%$ for the samples obtained from milling at $600 \mathrm{rpm}$ for $60 \mathrm{~min}$ indicating that some $\left(\mathrm{NH}_{2}\right)_{2} \mathrm{CO}$ was incorporated into amorphous structure of kaolinite.

The release profiles of $\left(\mathrm{NH}_{2}\right)_{2} \mathrm{CO}$ nutrients for the kaolinite- $\left(\mathrm{NH}_{2}\right)_{2} \mathrm{CO}$ (3:1 weight ratio) sample mixtures milled at $700 \mathrm{rpm}$ for fixed milling time $120 \mathrm{~min}$ and dispersed in water for different duration are shown in Figure 11.
Figure 12 shows the kaolinite- $\left(\mathrm{NH}_{2}\right)_{2} \mathrm{CO}$ (3:1 weight ratio) sample mixtures dispersed in distilled water. For the sample mixtures leached only for $60 \mathrm{~min}$, the release of urea reached over $20-25 \%$ indicating that sufficient duration is required to achieve complete amorphization of starting materials to allow incorporation of $\left(\mathrm{NH}_{2}\right)_{2} \mathrm{CO}$ into the amorphous kaolinite structure. When dispersing time was increased from 1 to $24 \mathrm{~h}$, the release of $\left(\mathrm{NH}_{2}\right)_{2} \mathrm{CO}$ nutrients into solution significantly increased, reaching around $30-40 \%$ at and other decreased for about $20 \%$ for the samples obtained by leaching for $168 \mathrm{~h}$, indicating that $\left(\mathrm{NH}_{2}\right)_{2} \mathrm{CO}$ was incorporated into the amorphous structure of kaolinite. 


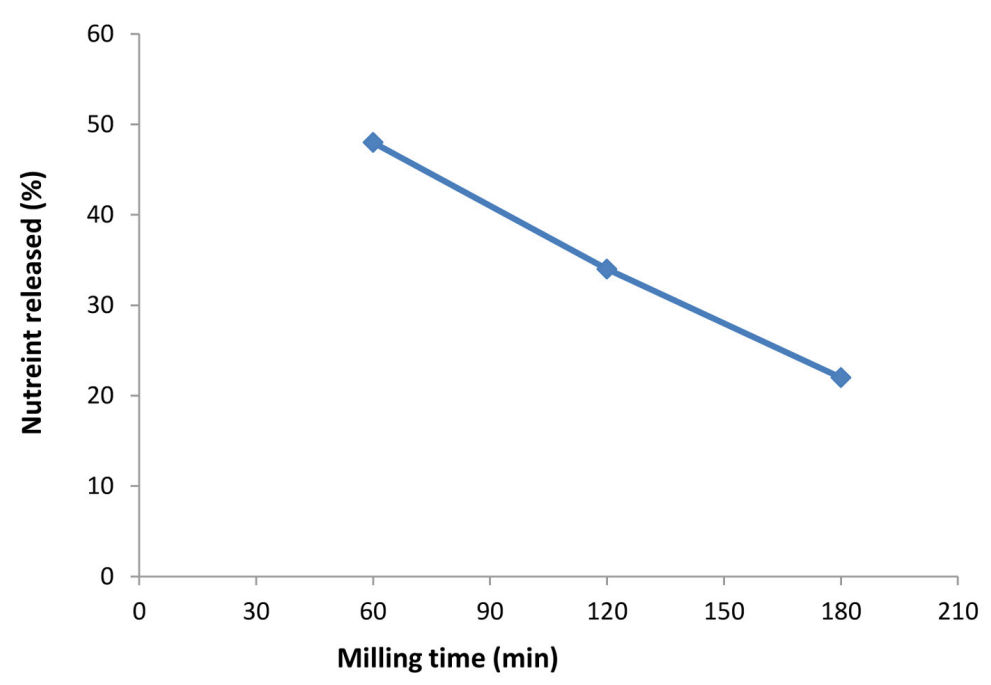

Fig. 11. Nutrients release profile of kaolinite- $\left(\mathrm{NH}_{2}\right)_{2} \mathrm{CO}(3: 1 \mathrm{wt}$ ratio) sample mixtures milled At $600 \mathrm{rpm}$ for $120(\mathrm{~min})$ milling time and dispersed in water for varied time 1,24 and $168 \mathrm{~h}$

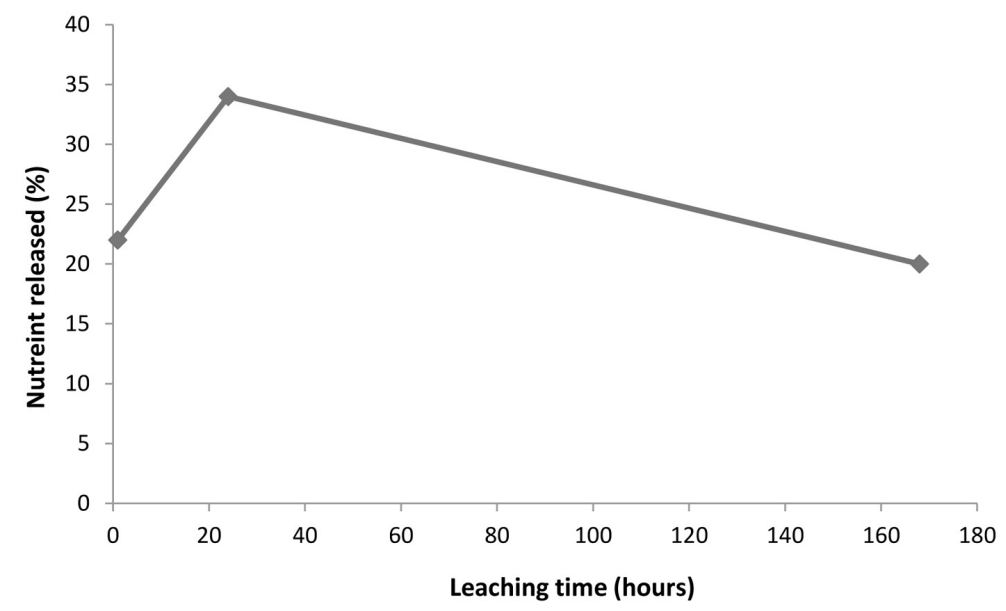

Fig. 12. Kaolinite- $\left(\mathrm{NH}_{2}\right)_{2} \mathrm{CO}$ (3:1 weight ratio) sample mixtures dispersed in distilled water

\section{CONCLUSIONS}

The release behavior experiments for noncoated intercalated urea-kaolinite samples revealed a dramatic decrease in the urea release after intercalation of urea into kaolinite. The incorporation of $\left(\mathrm{NH}_{2}\right)_{2} \mathrm{CO}$ compound into the structure of kaolinite was successfully achieved through mechanochemical route by a milling operation. The amount of kaolinite and its degree of amorphization played an important role in the incorporation process.

The findings in the present study can be summarized as follows:

a) A mill rotational speed of at least $400 \mathrm{rpm}$ was required to reduce all starting materials to amorphous state. Sufficient ball movement and collision was necessary for milling of the samples charged in the mill pots. b) Slow release behavior of the nutrients incorporated into kaolinite structure when dispersed in water was observed for sample mixtures milled at $400 \mathrm{rpm}$ and greater.

\section{REFERENCES}

1. Barjous, M. (1997). Pre-processing Investigation of the Kaolinite minerals of the Disi Sandstone Formation from the WadiAraba-Jordan.The Second Jordanian Mining Conference, Jordan.

2. Bayook, A. (1992). Batn El Ghoul Deposits as a Potential Source for Aluminum.M.Sc. Thesis, University of Jordan.

3. Borges R., S.F. Brunatto, A.A. Leita, G.S.G. De Carvalho, F. Wypych (2015). Solid-state mechanochemical activation of clay minerals and soluble phosphates mixtures to obtain slow-release fertilizers, Clay Minerals, 50, 153-162. 
4. Fukamachi C.R.B., Wypych F., Mangrich A.S. (2007). Use of $\mathrm{Fe} 3+$ ion probe to study the stability of ureaintercalated Kaolinite by electron paramagnetic resonance. Journal of Colloid and Interface Science, 313, 537-541.

5. Gardolinski J.E., Carrera C.M., Cantão M.P., Wypych F. (2000). Layered polymer Kaolinite nanocomposites. Journal of Materials Science, 35, 3113-3119.

6. Hrachova' J., Komadel P., Fajnor V.S. (2007). The effect of mechanical treatment on the structure of montmorillonite. Materials Letters, 61, 3361-3365.

7. Jones, C., Brown, B. D., Engel, R., Horneck, D., Olson-Rutz, K. (2013). Nitrogen fertiliservolatilisation. Montana State University, Extension, EB0208 new February, pp.1-6

8. Kottegoda, N., Munaweera, I., Madusanka, A.N., Karunaratne, V. (2013). Compositions for sustained release of agricultural macronutrients and process thereof. In. Google patents.

9. Kottegoda, N., Munaweera, I., Madusanka, N., Karunaratne, V. (2011). A green slow-release fertiliser composition based on urea-modified hydroxyapatite nanoparticles encapsulated wood. Curr.Sci., (00113891), 101.

10. LeBaron P., Wang Z., Pinnavaia T.J. (1999). Polymer-layered silicate nanocomposites: an overview. Applied Clay Science, 15, 11-29.

11. Li, Z.X., Wang, Q.C., Liu, X., Liu, K.C., Zhang, H. (2007). Studies of Applying effect of controlledrelease fertiliser on summer maize. J. Maize Sci., 6,024 .

12. Mako E., Kovacs A., Horvath E., Kristof J. (2014). Kaolinite-potassium acetate and halloysite-potassium acetate complexes prepared by mechanochemical, solution and homogenization techniques: a comparative study. Clay Minerals, 49, 457-471

13. Man, P., Chan, Y.K., Dong, H.L., Choong, L.C., Jyung, C., Sung- Reol, L., et al. (2004). Intercalation of magnesium-urea complex into swelling clay. J. Phys. Chem.Solids, 65, 409-412.

14. Qiwu Zhang, Fumio Saito, (2012). A review on mechanochemical syntheses of functional materials, Advanced Powder Technology, 23 .523-531.

15. Rutkai, G., Mako, E., Kristof, T. (2009). Simulation and experimental study of intercalation of urea in Kaolinite. J.Colloid. Interf. Sci, 334, 56-69.

16. B. Roshanravan, S.M Soltani, F. Mahdavi, S. Abdul Rashid, M.K. Yusop (2014). Preparation of encapsulated urea-Kaolinite controlled release fertiliser and their effect on rice productivity, Chemical Speciation and Bioavailability, 26:4, 249-256.

17. Solihin, Q.W. Zhang, W. Tongamp, F. Saito, (2011). Mechanochemical synthesis of KaoliniteeKH2PO4 and Kaolinitee-NH4H2PO4 complexes for application as slow release fertilizers, Powder Technol. $212,354-358$.

18. Sun D., Li B., Li Y., Yu C., Zhang B., Fei H. (2011). Characterization of exfoliated/delamination $\mathrm{Ka}$ olinite.Materials Research Bulletin, 46, 101-104.

19. Urena-Amate, M.D., Boutarbouch, N.D., SociasViciana, M.d.M., Gonzalez-Pradas, E. (2011). Controlled release of nitrate from hydrotalcite modified formulations. Appl. Clay Sci., 52, 368-373.

20. Valaskova, M., Rieder, M., Matìka, V., Ėapkova, P., Sliva, A. (2007). Exfoliation/delamination of Kaolinite by low-temperature washing of Kaolinite-urea intercalates. Appl. Clay Sci., 35, 108-118.

21. Vizcayno C., Gutierrez R.M., Castello R., Rodriguez E., Guerrero C.E. (2010). Pozzolan obtained by mechanochemical and thermal treatments of Kaolinite. Applied Clay Science, 49, 405-413.

22. Wang, X.F., Liu, S.Q., Ning, G.H. (2006). Study on the N Utilisation Ratio and the Control Result of New Slow Controlled Release Fertilisers. Acta Agric. Bor.-Sinica, S2.

23. Zhao, S.M., Tang, H., Wang, Y.M., Zhou, L.H. (2003). Study Situation and Developing Prospect of Coated Slow/Controlled Release Fertilisers.Sci. Technol. Chem. Ind., 11, 50-54. 